\title{
Climate change in the mountain cryosphere: impacts and responses
}

\author{
Carolina Adler $^{1}\left(\mathbb{D} \cdot\right.$ Christian Huggel $^{2} \cdot$ Ben Orlove $^{3} \cdot$ Anne Nolin $^{4}$
}

Received: 24 April 2019 / Accepted: 25 April 2019 / Published online: 11 May 2019

(C) The Author(s) 2019

\section{Introduction}

Addressing the impacts of climate change in the highmountain cryosphere and downstream regions, as well as responses to these impacts, has increasingly been the focus of research activities in recent years (e.g. Huss et al. 2017; Milner et al. 2017; Vuille et al. 2018). Studies aim at documenting and enhancing our understanding of processes and drivers related to these impacts, the extent of their negative effects, and the perception of these problems from the perspective of those affected. In parallel, the Intergovernmental Panel on Climate Change (IPCC) has presented an opportunity in its sixth assessment cycle (AR6) to address and respond to knowledge gaps on climate change impacts in the highmountain cryosphere, further motivating the research activity seen on the topic.

The IPCC Special Report on the Ocean and Cryosphere in a Changing Climate (SROCC) will present state-of-the-art knowledge on observations and detection of climatic signals manifesting as changes in the mountain cryosphere, their resulting impacts, and state of adaptation responses in the high-mountains context. The cross-chapter paper on "Mountains" in the IPCC AR6 Working Group II contribution on impacts, vulnerability and adaptation, on the other hand, is set to place greater focus on impacts and adaptation to climate change in mountain regions more broadly, and consequences for sustainable mountain development.

Carolina Adler

carolina.adler@giub.unibe.ch

1 Mountain Research Initiative, c/o Institute of Geography, University of Bern, Hallerstrasse 12, 3012 Bern, Switzerland

2 Department of Geography, University of Zurich, Winterthurerstrasse 190, 8057 Zurich, Switzerland

3 School of International and Public Affairs, Columbia University, 420 West 118th St, New York, NY 10027, USA

4 Department of Geography, University of Nevada, Reno, 1664 N. Virginia St., Reno, NV 89557, USA
Through this special issue, we sought to compile, interrelate and highlight cases and studies as contributions that the mountain research community can make to this AR6 assessment process and help address key knowledge needs that respond to pressing and relevant issues for our society at large. We also sought to call upon cases that address the relevant aspects, conditions and mechanisms that enable effective response actions through adaptation to climate change. This is particularly important, given that an evidentiary basis is needed to identify those "fit-for-purpose" actions that are congruent with the mountain context, the needs of people affected, and the scale of the problem.

\section{Impacts-observed and projected impacts in mountains in a changing climate for mountain cryosphere}

The first set of papers in this special issue present a comprehensive perspective on effects of climate change on different components and processes of the mountain cryosphere, including associated impacts, spanning from the South American Andes over to the Alps in Europe, High Asia and a continental scale perspective of Russia. Khromova et al. (2019, this issue) review past glacier changes from the Caucasus in the southwest to Kamtchatka and Koryak in the far east of the Russian territory. The glacier decline is not uniform over the whole region, ranging from 10 to $70 \%$, and depends on logical orographic and climatic factors.

The western regions of High Mountain Asia are the subject of the Armstrong et al. (2018, this issue). To estimate runoff in the large river basins of the Ganges, Brahmaputra, Indus, Amu Darya and Syr Darya, they used a simple temperature index melt model with forced remotely sensed snow cover from the moderate resolution imaging spectroradiometer (MODIS) and downscaled climate reanalysis data. With their extensive glacier areas, the Brahmaputra, Indus and Amu Darya receive the most input from exposed glacier ice (EGI) melt while the lower elevation Ganges and Syr Darya receive five times as much snowmelt as EGI melt. These new results show that 
melt from EGI is far less than shown in prior studies, and the role of seasonal snowmelt is large and critically important to water resources in the region.

Schaffer et al. (2019, this issue) stress the importance of the meltwater contribution of rock glaciers to end-of-summer streamflow in the semi-arid Chilean Andes. Rock glaciers are abundant in the latitude range of $29-35^{\circ} \mathrm{S}$, above 3500 m.a.s.1., yet information on their characteristics remains elusive. The authors outline the major challenges in determining water storage and melt from rock glaciers, including glacier area, glacier volume, ice and liquid water percentages, diurnal and seasonal melt patterns and discharge rates. While some of these factors have been quantified, basic data for modelling rock glaciers at the watershed scale is lacking. What is needed is a systematic assessment to create a database of hydrologically relevant rock glacier characteristics. This is especially critical in drought-prone mountain watersheds such as the semi-arid Andes.

The impacts of permafrost change and degradation on economic sectors becomes evident with the study of Duvillard et al. (2019, this issue) that analyses the damage to ski infrastructure in the French Alps related to permafrost degradation. Of the close to 1000 infrastructure elements located in permafrost areas, 24 were identified to have been affected by repeated disruption and deterioration. The cost of repair may easily be in the order of millions EUR. There is some evidence that more works and maintenance has been done since 2010 as compared to the previous two decades.

\section{Adaptation-experiences and strategies in mountain social-ecological systems to address climate-related changes in the cryosphere}

Adaptation to climate-related changes in the cryosphere, more specifically on framings, values, motivations and strategies adopted that underpin adaptation actions, are important considerations for how adaptation and resilience are to be assessed and evaluated in the long term. Orlove et al. (2019, this issue) take a considered look at social framings to characterise perceptions to glacier retreat in mountain communities, by inter-relating studies conducted in Peru, Italy and USA. They find that factors such as social ties and shared understandings of community histories, and their potential shared futures based on projections from their current experiences, facilitate an understanding of their current realities and actions that are socially relevant and appropriate in their context to deal with these changes.

Over the past years, the Hindu Kush Himalaya region has seen an enormous effort in research on glacier changes and related impacts on water and hazards research, at least partly motivated by the "glacier gate" due to an erroneous statement about the fate of Himalayan glaciers in the IPCC 4th Assessment Report (2007) (Bolch et al. 2012). Mukherji et al. (2019, this issue) draw on this important progress in the state of knowledge and extend the perspective towards ecosystem related services, so-called cryosphere services, to the mountain communities of this mountain region. Their review reveals that non-material services are less well documented in comparison with water supply or disservices such as natural hazards. Moreover, little research exists on how politics and power influence societal response to change in the cryosphere, suggesting a need for more research engaging across disciplinary boundaries.

A pertinent example of such research is the study by Nüsser et al. (2018, this issue) who examine the physical mechanisms and the social processes and context of artificial glaciers in Ladakh, India. They find that artificial glaciers are well suited to bridge the water scarce spring season before snow and glacier melt starts. However, their research also indicates that climatic variability, flood and mass movement events, and a contested integration in the local social context reduce their efficacy and make them questionable as a climate change adaptation strategy, as repeatedly promoted by some actors in the region.

Xenarios et al. (2018, this issue) offer a review of a number of impacts of climate change, and responses to these changes, in the Pamir and Tien Shan mountains in Central Asia. They note that observational meteorological data and natural hazards are incomplete, yet they are able to point at warming in recent decades, variable shifts in precipitation and a general trend towards an earlier date of annual peak runoff in streams. They ran climate models for two sites in the region for several time periods through the end of the century for RCP2.6, RCP4.5 and RCP8.5, and find warming in both, but variable precipitation trends. They note concerns of local residents, whose livelihoods focus on agriculture and pastoralism, over the lack of availability of water and pasture. They report on a number of adaptation projects in agricultural and water management, supported by local communities, national governments and international donors, though they find that these generally lack adequate scientific information on which to base interventions. They underscore the difficulties placed by knowledge gaps and data constraints on climate change adaptation in mountainous Central Asia. They find other barriers to effective adaptation as well, focusing particularly on the centralised, hierarchical character of national governments and the associated tensions between central governments and remote mountain regions and on the lack of cooperation in transboundary governance of water resources originating in these mountains; these two, taken together, impede effective long-term planning.

Yager et al. (2019, this issue) use multiple lines of evidence to ascertain the extent of changes observed and experienced by indigenous pastoral communities in the Sajama region of Bolivia, with changes in the cryosphere that manifest as changes in water availability for mountain peatland pastures 
(bofedales) and the pastoral livelihoods that depend on them. By combining satellite images, vegetation surveys and local knowledge, they describe critical changes in land cover, such as a reduction by almost one-third in the area of healthy bofedales in 1986 compared with 2016, and a fourfold increase in area by dry mixed grasses in the same period. Community inputs help to explain and contextualise these observations, with changes in water management, pastoral practices and other social factors cited as exacerbating these shifts and complex interactions with climate change in socialecological systems.

\section{Policy—responses to address and manage risks associated with changes in the mountain cryosphere}

Rasmussen (2018, this issue) examines policy issues which shape a case of mountain cryosphere tourism. He focuses on "The Route of Climate Change", a circuit in Peru's Huascaran National Park which offers visitors the opportunity to learn about climate change by visiting a rapidly shrinking glacier, Pastoruri, and learning of its effects on physical, biological and social systems - an example of what has been termed "last chance" tourism. He discusses the concept of "conservation landscapes", frequently used in national parks and other protected areas to preserve endangered species and places and examines the narratives of past and future states of landscapes which inform it. He shows that members of the local indigenous community which has long held use-rights to areas within the park understand the conservation of landscapes very differently from the park managers, focusing on their long history of managing resources. He traces disagreements between the park and the community over land use and management of tourist activities, showing that these are not only economic conflicts over resources but cultural tensions over which narratives to employ. He suggests that the range of possible interpretations of the notion of conservation landscapes allows the park and the community to establish a working arrangement, though not full agreement, over management practices and goals.

Huggel et al. (2018, this issue) review for the first time the treatment of loss and damage (L\&D) in the mountain cryosphere context in the published literature. They show that L\&D has been defined in a variety of ways, all linked to economic and non-economic harms associated with climate change, often as ones that are not addressed by mitigation or adaptation. They present cases of mountain cryosphere L\&D in many areas of the word, mostly developing countries.

\section{Outlook and prospects for mountain research to address knowledge needs}

The papers in this special issue reveal many advances made on how issues pertaining to climate-related changes in the cryosphere are framed and investigated in the mountain context. Considerable and commendable attention is given to combining multiple lines of evidence to base conclusions, and the need for integrating these within frameworks that consider both the biophysical and socio-economic factors and key interactions in mountains as social-ecological systems. However, insights gained have also revealed key questions and topics that still remain under-researched and that warrant further attention. For instance, one set of examples consists of questions on how politics and differentiated power relations do or could influence societal response to change in the cryosphere in key climate policy realms such as $L \& D$, requiring research that engages meaningfully across disciplinary boundaries (Huggel et al. 2018, this issue). Another example is the role of 'community' in promoting practices that empower and engage people in joint problem-framing based on shared experiences and values (Orlove et al. 2019, this issue), and conversely, the deterioration of collective practices that impact on common pool resources that are also affected by a changing cryosphere (Yager et al. 2019, this issue). These are examples of key, yet complex human dimensions that could underpin much of the successes expected with adaptation going forward (McDowell et al. 2019).

From a mountain research perspective, and through the experiences that some of us observe as lead authors in IPCC AR6, we also call upon a greater emphasis to reviews and syntheses of evidence that address the relevant aspects, conditions and mechanisms that could inform and support adaptation actions and facilitate an effective reduction of net losses of what is valued. Mountain social-ecological systems around the world are diverse, as the papers in this special issue demonstrate, with each mountain region hosting unique biophysical and socio-cultural conditions. To better understand, compare and aggregate insights on how these diverse systems function, and what the enablers and barriers to the functioning and sustainable development are, more research attention is needed on systematic inter-comparability of cases and transferability of evidence, beyond generalisability (Adler et al. 2018). This will not be achievable without a stronger and deeper engagement among various disciplines of social and physical sciences, and with other knowledge systems. The enormous challenges that mountain regions face towards sustainable development constraints of climate and cryosphere change, and social and economic change, require a similarly large effort by the mountain research community and the networks that support it.

Acknowledgements We wish to thank all who responded to the call for this special issue, and to the authors who committed to this publication. This editorial note has been made available Open Access by the Mountain Research Initiative, with support from the Swiss Academy of Sciences. 
Open Access This article is distributed under the terms of the Creative Commons Attribution 4.0 International License (http:// creativecommons.org/licenses/by/4.0/), which permits unrestricted use, distribution, and reproduction in any medium, provided you give appropriate credit to the original author(s) and the source, provide a link to the Creative Commons license, and indicate if changes were made.

\section{References}

Adler C, Hirsch Hadorn G, Breu T, Wiesmann U, Pohl C (2018) Conceptualizing the transfer of knowledge across cases in transdisciplinary research. Sustain Sci 13:179-190. https://doi.org/10.1007/ s11625-017-0444-2

Armstrong RL, Rittger K, Brodzik MJ, Racoviteanu A, Barrett AP, Khalsa S-JS, Raup B, Hill AF, Khan AL, Wilson AM, Kayastha RB, Fetterer F, Armstrong B (2018) Runoff from glacier ice and seasonal snow in high Asia: separating melt water sources in river flow. Reg Environ Chang. https://doi.org/10.1007/s10113-0181429-0

Bolch T, Kulkarni A, Kääb A, Huggel C, Paul F, Cogley JG, Frey H, Kargel JS, Fujita K, Scheel M, Bajracharya S, Stoffel M (2012) The state and fate of Himalayan glaciers. Science 336:310-314. https:// doi.org/10.1126/science. 1215828

Duvillard P-A, Ravanel L, Marcer M, Schoeneich P (2019) Recent evolution of damage to infrastructure on permafrost in the French Alps. Reg Environ Chang. https://doi.org/10.1007/s10113-019-01465-z

Huggel C, Muccione V, Carey M, James R, Jurt C, Mechler R (2018) Loss and damage in the mountain cryosphere. Reg Environ Chang. https://doi.org/10.1007/s10113-018-1385-8

Huss M, Bookhagen B, Huggel C, Jacobsen D, Bradley RS, Clague JJ, Vuille M, Buytaert W, Cayan DR, Greenwood G, Mark BG, Milner AM, Weingartner R, Winder M (2017) Toward mountains without permanent snow and ice. Earth's Future 5:418-435. https://doi.org/ 10.1002/2016ef000514

Khromova T, Nosenko G, Nikitin S, Muraviev A, Popova V, Chernova L, Kidyaeva V (2019) Changes in the mountain glaciers of continental Russia during the twentieth to twenty-first centuries. Reg Environ Chang. https://doi.org/10.1007/s10113-018-1446-z

McDowell G, Huggel C, Frey H, Wang FM, Cramer K, Ricciardi V (2019) Adaptation action and research in glaciated mountain systems: are they enough to meet the challenge of climate change? Glob Environ Chang 54:19-30. https://doi.org/10.1016/j.gloenvcha. 2018.10.012

Milner AM, Khamis K, Battin TJ, Brittain JE, Barrand NE, Füreder L, Cauvy-Fraunié S, Gíslason GM, Jacobsen D, Hannah DM, Hodson AJ, Hood E, Lencioni V, Ólafsson JS, Robinson CT, Tranter M, Brown LE (2017) Glacier shrinkage driving global changes in downstream systems. Proc Natl Acad Sci 114:9770-9778. https:// doi.org/10.1073/pnas.1619807114

Mukherji A, Sinisalo A, Nüsser M, Garrard R, Eriksson M (2019) Contributions of the cryosphere to mountain communities in the Hindu Kush Himalaya: a review. Reg Environ Chang. https://doi. org/10.1007/s10113-019-01484-w

Nüsser M, Dame J, Kraus B, Baghel R, Schmidt S (2018) Sociohydrology of "artificial glaciers" in Ladakh, India: assessing adaptive strategies in a changing cryosphere. Reg Environ Chang. https:// doi.org/10.1007/s10113-018-1372-0

Orlove B, Milch K, Zaval L, Ungemach C, Brugger J, Dunbar K, Jurt C, $\mathrm{Bu}$ Y (2019) Framing climate change in frontline communities: anthropological insights on how mountain dwellers in the USA, Peru and Italy adapt to glacier retreat. Reg Environ Chang. https:// doi.org/10.1007/s10113-019-01482-y

Rasmussen MB (2018) Rewriting conservation landscapes: protected areas and glacial retreat in the high Andes. Reg Environ Chang. https://doi.org/10.1007/s10113-018-1376-9

Schaffer N, MacDonell S, Réveillet M, Yáñez E, Valois R (2019) Rock glaciers as a water resource in a changing climate in the semiarid Chilean Andes. Reg Environ Chang. https://doi.org/10.1007/ s10113-018-01459-3

Vuille M, Carey M, Huggel C, Buytaert W, Rabatel A, Jacobsen D, Soruco A, Villacis M, Yarleque C, Elison Timm O, Condom T, Salzmann N, Sicart J-E (2018) Rapid decline of snow and ice in the tropical Andes - impacts, uncertainties and challenges ahead. Earth Sci Rev 176:195-213. https://doi.org/10.1016/j.earscirev. 2017.09.019

Xenarios S, Gafurov A, Schmidt-Vogt D, Sehring J, Manandhar S, Hergarten C, Shigaeva J, Foggin M (2018) Climate change and adaptation of mountain societies in Central Asia: uncertainties, knowledge gaps, and data constraints. Reg Environ Chang. https:// doi.org/10.1007/s10113-018-1384-9

Yager K, Valdivia C, Slayback D, Jimenez E, Meneses RI, Palabral A, Bracho M, Romero D, Hubbard A, Pacheco P, Calle A, Alberto H, Yana O, Ulloa D, Zeballos G, Romero A (2019) Socio-ecological dimensions of Andean pastoral landscape change: bridging traditional ecological knowledge and satellite image analysis in Sajama National Park, Bolivia. Reg Environ Chang. https://doi.org/10.1007/ s10113-019-01466-y

Publisher's note Springer Nature remains neutral with regard to jurisdictional claims in published maps and institutional affiliations. 